\begin{tabular}{lccc} 
& GOSPODARKA & SUROWCAMI & MINERALNYMI \\
\hline Tom 29 & 2013 & Zeszyt 3 \\
& & DOI 10.2478/gospo-2013-0032 &
\end{tabular}

ROMAN ŚCIGAŁA*

\title{
A mining extraction system with advancing longwall as a method of protecting technical objects and an element of rational deposit management
}

\section{Introduction}

Underground mining in the Upper Silesian Basin is very often conducted under highly urbanized areas. This leads to many adverse changes to the natural environment, as well as to building structures and elements of urban technical infrastructure. In order to protect these objects, protective pillars are usually designed. As is well known, extraction within these pillars may only be carried out taking special actions to insure proper protection of existing infrastructure against mining damages. Mines usually refrain from the extraction of protective pillars, which results in the certain loss of reserves and interferes with the rational management of the deposit. This raises the question of whether conditions of safe and effective extraction of such pillars presently exist.

There are several extraction methods that can be used for the limitation of underground mining impact, depending on the type of object to be protected (Chudek et al. 2004; Knothe 1984; Kratsch 1983; Piwowarski et al. 1995). Unfortunately, present technical and economic conditions dictate that the majority of them cannot be used due to the complex shape of the extraction front, which ensures proper conditions for minimizing deformations at the location of an object to be protected. One of the few methods that seems to be feasible today is a longwall extraction system using a so-called "advancing longwall" (Knothe 1984). This method can be used for the protection of linear objects like railways, motorways, pipelines,

Ph.D. Eng., Politechnika Śląska, Gliwice; e-mail: roman.scigala@polsl.pl 
etc. Its application to the extraction of protective pillars designed for such objects could undoubtedly contribute to improving the management of the deposit, although it should be noted that, in this case, the implementation of such a project from a practical point of view poses many technical problems.

This extraction method employs three longwalls, where the central longwall advances side-walls (Fig. 1). According to the central longwall advance $s$ and its length $L$, different reductions in surface tilt and horizontal strain can be achieved of up to $50 \%$ in relation to normal linear front shape. It is thus of special importance to properly determine the dimensions of an advancing longwall. S. Knothe described this system with some additional information concerning suggested longwall dimensions (Knothe 1984):

$$
s_{\min }=0.8 H / \operatorname{tg} \beta, \quad L_{\text {opt }}=0.55 H / \operatorname{tg} \beta+2 d
$$

where:

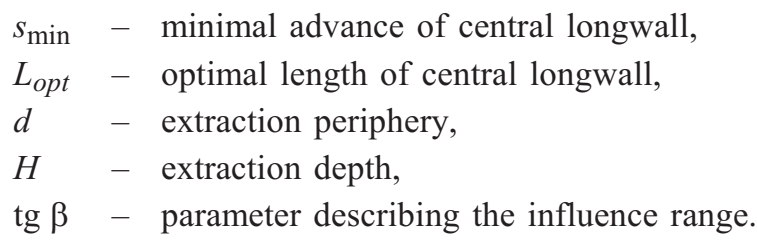

There is a lack of existing documentation offering broader analysis of the impact of various factors, including in particular the dimensions of the longwall and its speed, and the impact of the properties of the rock mass on the reduction in values of deformations along the longitudinal axis of a linear object. Thus, this paper presents a detailed discussion focused on the influence of the central advancing longwall's dimensions on the reduction in tilt and horizontal strain.

The considerations were prepared on the basis of an interactive theoretical model built on the assumptions of the W. Budryk-S. Knothe theory. Practical realization has been worked

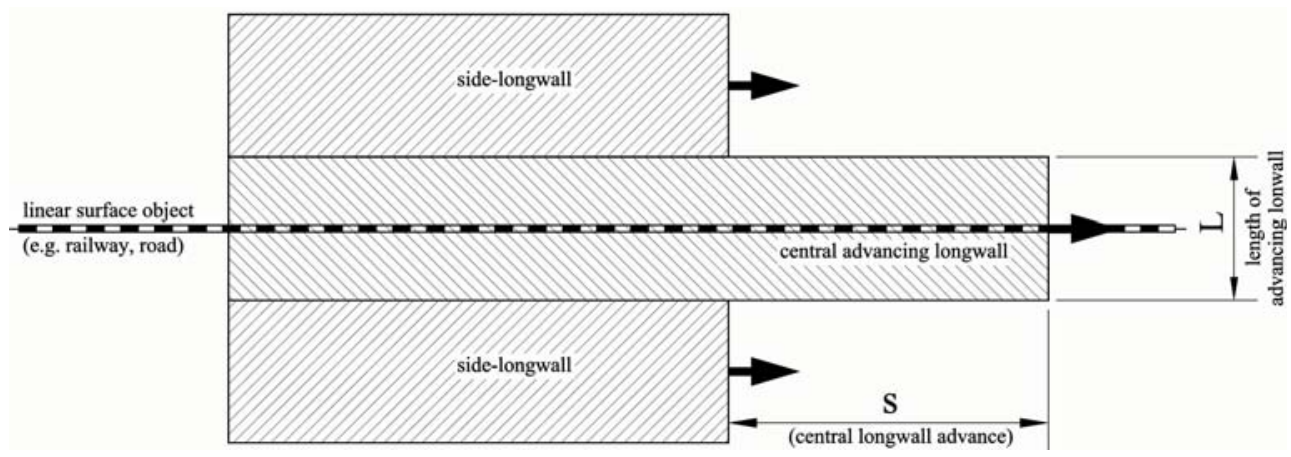

Fig. 1. Sketch illustrating the extraction system with advancing longwall

Rys. 1. Schemat ilustrujący eksploatację systemem ścianowym ze ścianą wyprzedzającą 
out using Wolfram Mathematica 9 software (Wolfram et al. 1988-2013). Thanks to this software, it was possible to solve all the necessary equations, and then use their solutions to build an interactive calculation model. The developed model enables the performance of real-time simulation of three longwalls extraction and their influence on the subsidence trough profile along the longitudinal axis of a hypothetical linear object located at the surface level. Below, the basic characteristics of this model are presented.

\section{The W. Budryk-S. Knothe model used in Wolfram Mathematica system for analyses of influences of extraction with advancing longwall}

The model prepared for the purpose of this study contains a solution for both the asymptotic state of deformation, as well as for the transient state. It was assumed that the model should allow the analysis of any front shape made up of three, rectangular longwalls. Accordingly, it is possible to analyze the extraction system associated with the advancing longwall, but a stepped configuration can also be realized or an instance with a delay of the central longwall (Fig. 2).
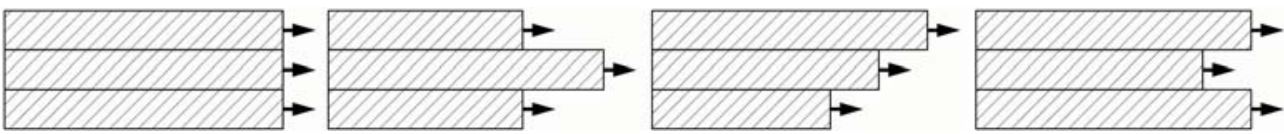

Fig. 2. Different possibilities of extraction front shaping made up of three longwalls

Rys. 2. Różne możliwości analizy układu frontu eksploatacyjnego złożonego z trzech ścian

For the purpose of building a model for the asymptotic state of deformation, the basic relationship of the W. Budryk-S. Knothe theory was employed, which defines the subsidence of a considered point at the surface caused by the extraction of mining field area $P$ :

$$
w(s, t)=-\frac{a \cdot g}{r^{2}} \iint_{P} f(x-s, y-t) d P
$$

where:

$g \quad-$ thickness of coal seam,

$s$, $\mathrm{t}$ - coordinates of calculation point $M$ in Cartesian coordinate system,

$x, y-$ coordinates of elementary extraction field $d P$,

$P \quad-$ the whole extracted area of coal seam,

$a \quad-$ the coefficient of roof control.

$r \quad-$ the main influence range.

The other deformation indices were calculated as corresponding derivatives of subsidence with respect to a given direction according to the following equations (Knothe 1953a): 


$$
\begin{gathered}
T_{x}=\frac{\partial w}{\partial x}, \quad T_{y}=\frac{\partial w}{\partial y}, \quad K_{x} \cong \frac{\partial^{2} w}{\partial x^{2}}, \quad K_{y} \cong \frac{\partial^{2} w}{\partial y^{2}}, \\
\varepsilon_{x}=-B \cdot \frac{\partial^{2} w}{\partial x^{2}}, \quad \varepsilon_{y}=-B \cdot \frac{\partial^{2} w}{\partial y^{2}}
\end{gathered}
$$

where $B$ is a parameter of proportionality between horizontal displacement and tilt in the S. Avershin relationship.

For a description of land surface deformation changes over time (so called "transient subsidence"), the S. Knothe assumption was used. It states that for a given surface point, its rate of subsidence is proportional to the difference between asymptotic value of subsidence $w_{k}$ and its momentary (transient) value $w(\tau)$ (Knothe 1953b):

$$
\frac{d w}{d \tau}=c \cdot\left(w_{k}(\tau)-w(\tau)\right)
$$

where:

$w_{k}(\tau)-$ asymptotic value of subsidence at the time $\tau$,

$w(\tau) \quad-$ the value of transient subsidence at the time $\tau$,

$c \quad-$ coefficient of subsidence rate (the so called "time factor").

Assuming that $w_{k(\tau)} \neq$ const (due to continuous movement of the extraction front), the solution to equation (4) is relatively complicated for practical use (Knothe 1953b):

$$
w(\tau)=\int_{0}^{\tau} f(\lambda \cdot v) \cdot v d \lambda-e^{-c t} \int_{0}^{\tau} f(\lambda \cdot v) \cdot v \cdot e^{c \lambda} d \lambda
$$

Using the Wolfram Mathematica 9 system, the differential equation (4) was solved, taking into account condition $w_{k} \rightarrow w_{k}(\tau)$, where $\tau$ symbolizes the time of extraction front location (for $\tau=0$ extraction starts), which moves with velocity $v$. For a rectangular shaped extraction front (Fig. 3) one performs the following calculation of transient subsidence:

$$
w(\tau, . .)=\frac{w_{\max }}{4}\left(A(\tau, . .) \cdot e^{\frac{c\left(c r^{2}+4 \pi s v\right)}{4 \pi v^{2}}} \cdot e^{-c \tau}-D \cdot B(\tau, . .)\right), \quad v>0, \quad r>0
$$

where: 


$$
\begin{array}{r}
A(\tau, . .)=\operatorname{erf}\left(\frac{\sqrt{\pi} \cdot s}{r}+\frac{c \cdot r}{2 \sqrt{\pi} \cdot v}\right)+\operatorname{erf}\left(\frac{-c \cdot r^{2}+2 \pi \cdot v \cdot(v \cdot \tau-s)}{2 \sqrt{\pi} \cdot v \cdot r}\right) \\
B(\tau, . .)=\operatorname{erf}\left(\frac{\sqrt{\pi} \cdot s}{r}\right)-\operatorname{erf}\left(\frac{\sqrt{\pi} \cdot(s-v \cdot \tau)}{r}\right) \\
D=\operatorname{erf}\left(\frac{\sqrt{\pi}(p-t)}{r}\right)-\operatorname{erf}\left(\frac{\sqrt{\pi}(q-t)}{r}\right), \quad \operatorname{erf}(\xi)=\frac{2}{\sqrt{\pi}} \int_{0}^{\xi} e^{-\lambda^{2}} d \lambda
\end{array}
$$

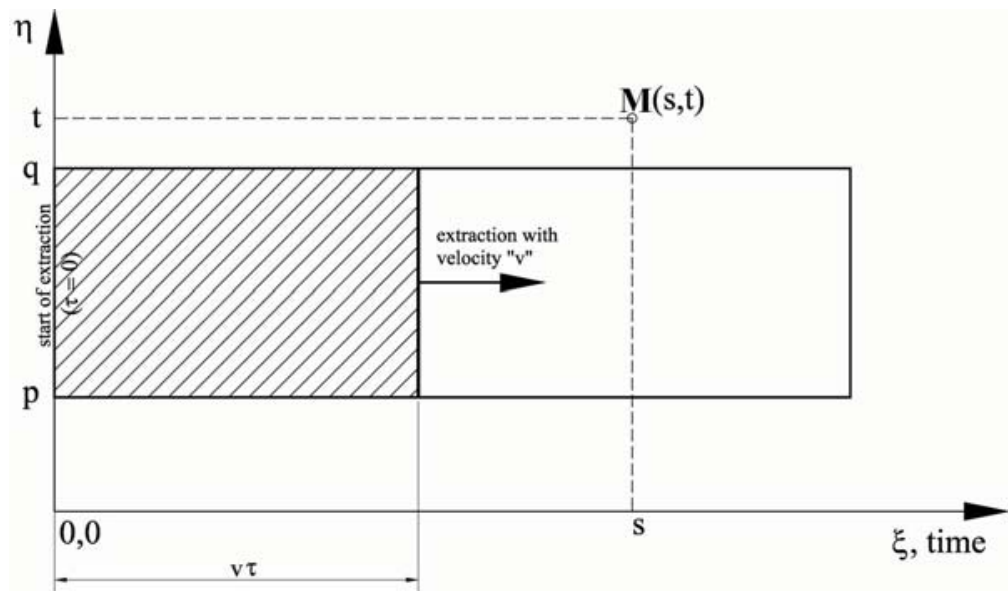

Fig. 3. Sketch of single rectangular longwall with elements used in formula (6)

Rys. 3. Schemat obliczeniowy objaśniający elementy zależności (6)

Accordingly, taking equation (6), the necessary formulae for calculation of tilt $T(\tau)$ and horizontal strain $\varepsilon(\tau)$ were derived using dependencies (3). They are not presented here due to paper volume limitations.

The obtained equations were then used for building an interactive model that allows the performance of real-time analysis of the impact of selected mining-geological factors on the values of deformation indices on the surface along the computational line located above extraction fields. This line represents a hypothetical course of technical infrastructure's linear object on the surface. Fig. 4 presents a snapshot of the model working on the example of solutions for tilt and horizontal strain.

As one can see in Fig. 4, the user has the possibility to change the model's parameters by simply dragging proper controls grouped on the left side. There are options for changing the following parameters:

— extraction front shape using the "face advance..." option. This option enables arbitrary changing of the advance relation between considered longwalls, so it is possible to set any shape of active extraction edge, as presented in Fig. 2, 


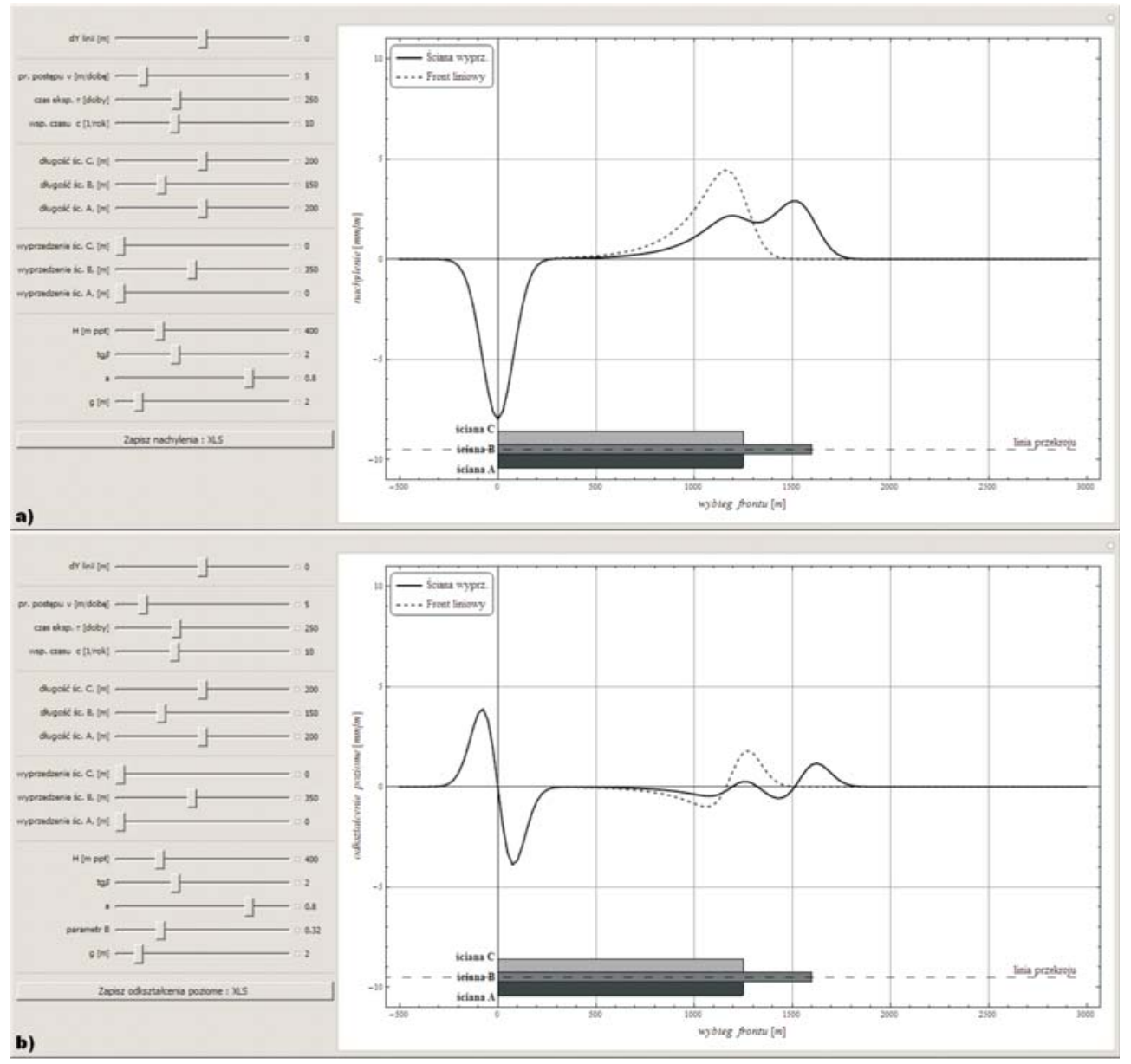

Fig. 4. Interactive model of transient tilt (a) horizontal strain (b), caused by underground extraction with advancing longwall, worked out using Wolfram Mathematica software

Rys. 4. Interaktywny model nieustalonych nachyleń (a) i odkształceń poziomych (b), wywołanych eksploatacją ze ścianą wyprzedzającą zbudowany za pomocą systemu Wolfram Mathematica

— individual length of each longwall $L$ and extraction velocity $v$,

- extraction depth $H$ and face height $g$,

- coefficient of roof control $a$,

- rock mass properties expressed by means of parameters $\operatorname{tg} \beta$ and $c$.

Automatically or manually changing the time $\tau$ through the use of the dedicated controls, we get the simulation of extraction. It is assumed that extraction starts at $\tau=0$ (see Fig. 3) from the west side of the model and moves eastward. Changes to any model parameters are reflected immediately on the model graph (Fig. 4 on the right). This graph presents the course of a given deformation index, calculated along the longitudinal line for the considered extraction shape (solid line) and for the influences of the linear front shape (dashed line). 
Additionally, the user can shift the location of the calculation line toward the north or south using the " $d Y$ " control ( $d Y=0$ means central location of the calculation line). The location of the calculation line is presented on the graph using a horizontal, dashed line. The results of any simulation step can also be written to an Excel (XLS) file for further processing.

\section{The calculation results}

Using the developed model, the multi-option calculations were performed aimed at the determination of dependencies between the most important factors influencing the tilt $T$ and horizontal strain $\varepsilon$ values of the transient subsidence trough profile directly above the moving extraction edge. The following factors and their combinations were taken into consideration:

— the advance $s$ of central longwall in relation to lateral walls (Fig. 1). The following advances were analyzed: $s=0$ (the linear-shaped front), $s=0.2 r$ up to $s=2.0 r$, with $0.2 r$ increment,

— the length $L$ of central longwall: $L=0.500 r, 0.625 r, 0.750 r, 1.000 r$,

— the extraction front velocity $v: v=5 \mathrm{~m} /$ day, $10 \mathrm{~m} /$ day, $20 \mathrm{~m} /$ day,

- the rock mass properties, expressed by different values of time factor $c: c=2.51$ year, $c=10.01 /$ year, $c=201 /$ year and $c=401 /$ year. The first value is representative for strong rock mass where deformation process is "slow", the next values represent gradually weaker rock masses with relatively quick transition of deformations from the extracted seam to the surface. These values exceed the interval suggested by S. Knothe (1984), but they are documented by other authors for the present conditions of underground extraction in the Upper Silesia Basin (inter alia: Sroka 1999; Strzałkowski 1998).

In the first step, for each combination of the above mentioned factors, the courses of transient tilt and horizontal strain along the symmetrically located, longitudinal line were calculated (see Fig. 4). Then, for each case, extreme values of: tilt $T_{\text {ekstr }}^{\text {wyprz }}$, tensile strain $\varepsilon_{\text {ekstr+ }}^{\text {wyprz }}$ and compressive strain $\varepsilon_{\text {ekstr- }}^{\text {wyprz }}$ were examined in the range of influence of the moving extraction edge.

Finally, all combinations were brought together and recalculated using dimensionless reduction coefficients: $\delta_{T}, \delta_{\varepsilon^{+}}, \delta_{\mathcal{E}_{-}}$, calculated as:

$$
\delta_{T}=\frac{T_{\text {ekstr }}^{\text {wyprz }}}{T_{\text {ekstr }}^{\text {lin }}}, \quad \delta_{\varepsilon-}=\frac{\varepsilon_{\text {ekstr- }}^{\text {wyprz }}}{\varepsilon_{\text {ekstr- }}^{\text {lin }}}, \quad \delta_{\varepsilon+}=\frac{\varepsilon_{\text {ekstr }+}^{\text {wyprz }}}{\varepsilon_{\text {ekstr }+}^{\text {lin }}}
$$

where $T_{e k s t r}^{\text {lin }}, \varepsilon_{\text {ekstr }}^{\text {lin }}$ present the extreme values of tilt and horizontal strain calculated for a simple linear extraction front. The graphs presenting the distribution of coefficients: $\delta_{T}$ and $\delta_{\varepsilon}$, in relation to the analysed factors, are shown in Figures 5-10 (graphs for $\delta_{\varepsilon^{+}}$ are not presented here due to the limited volume of this paper). 


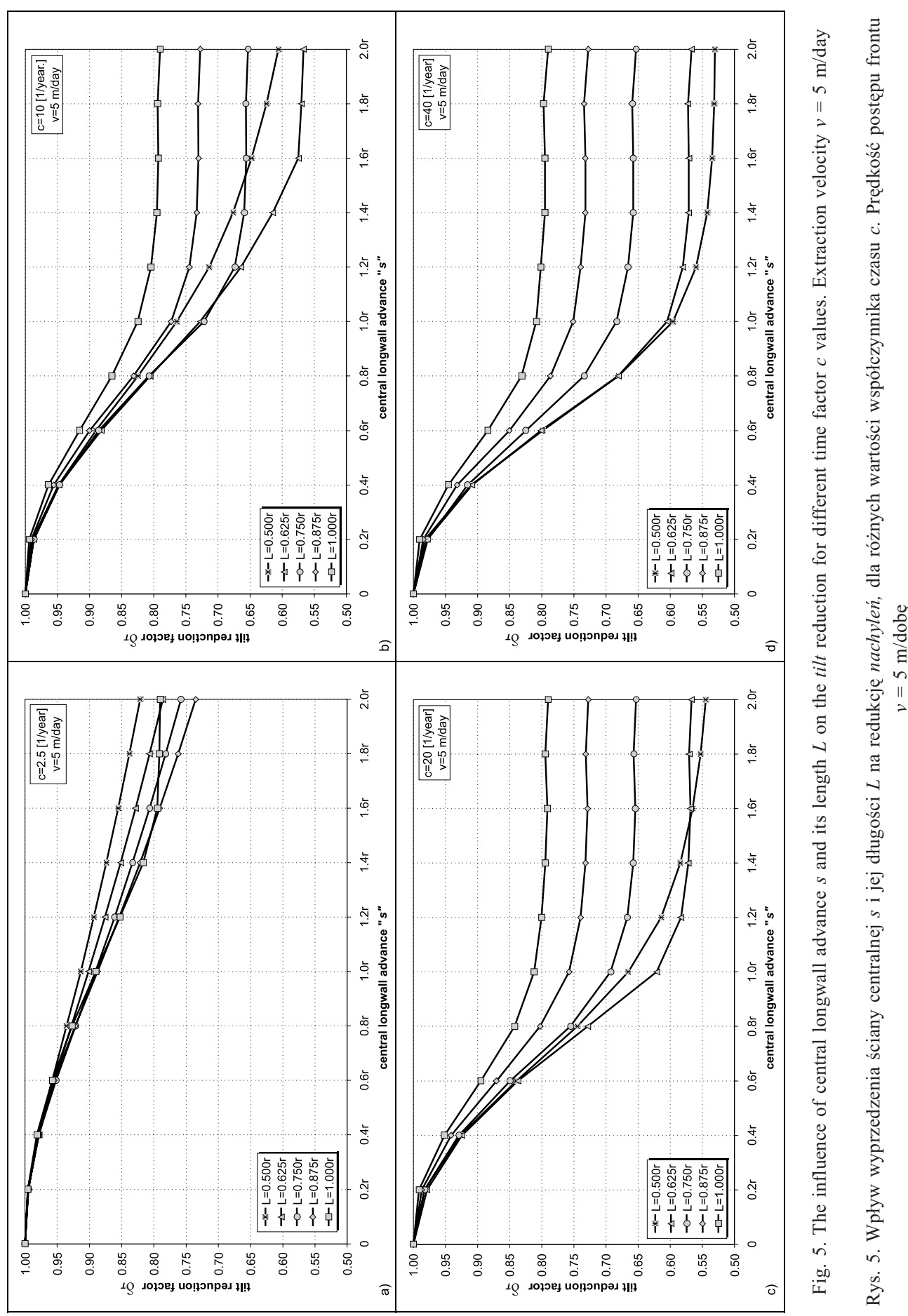




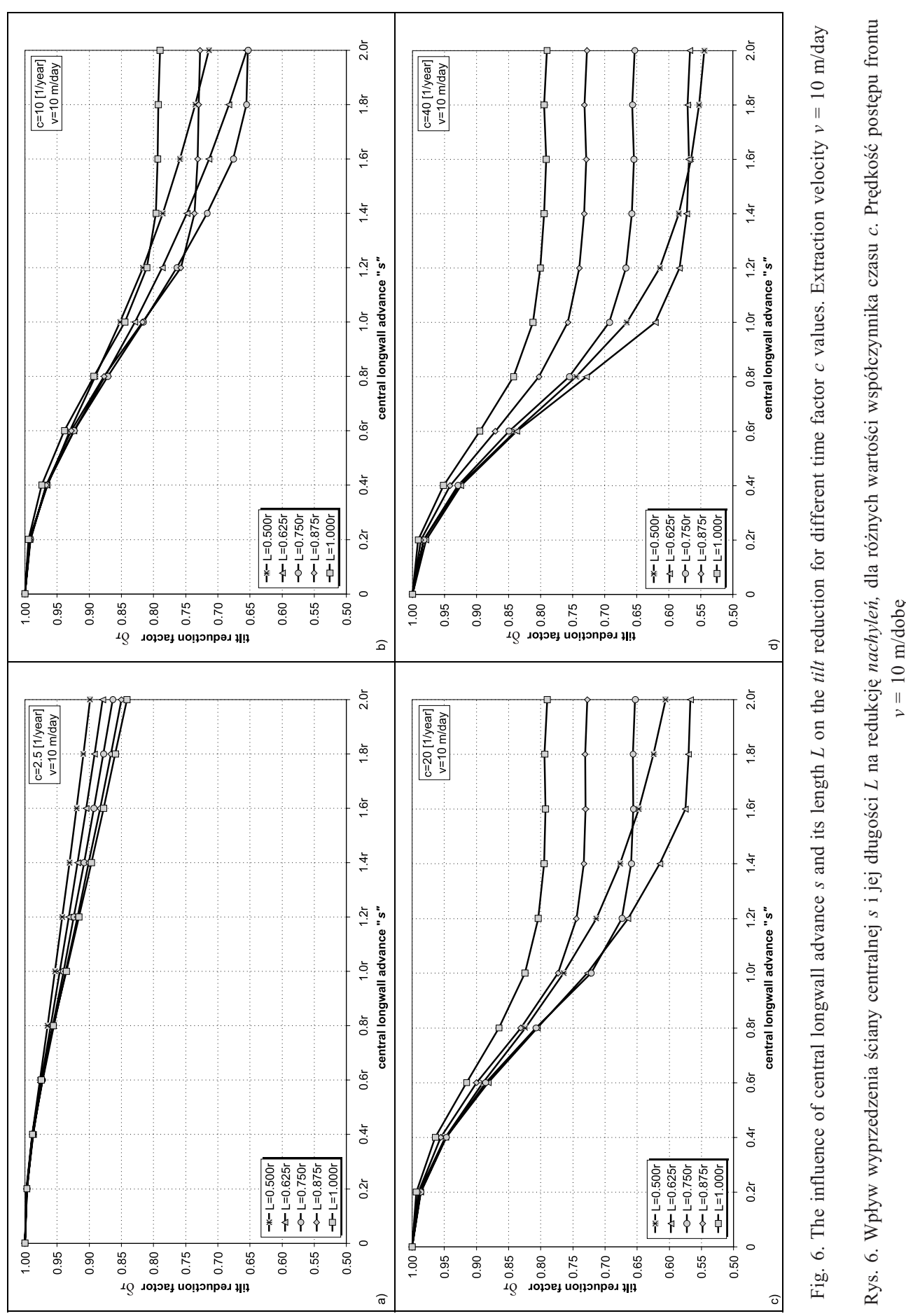




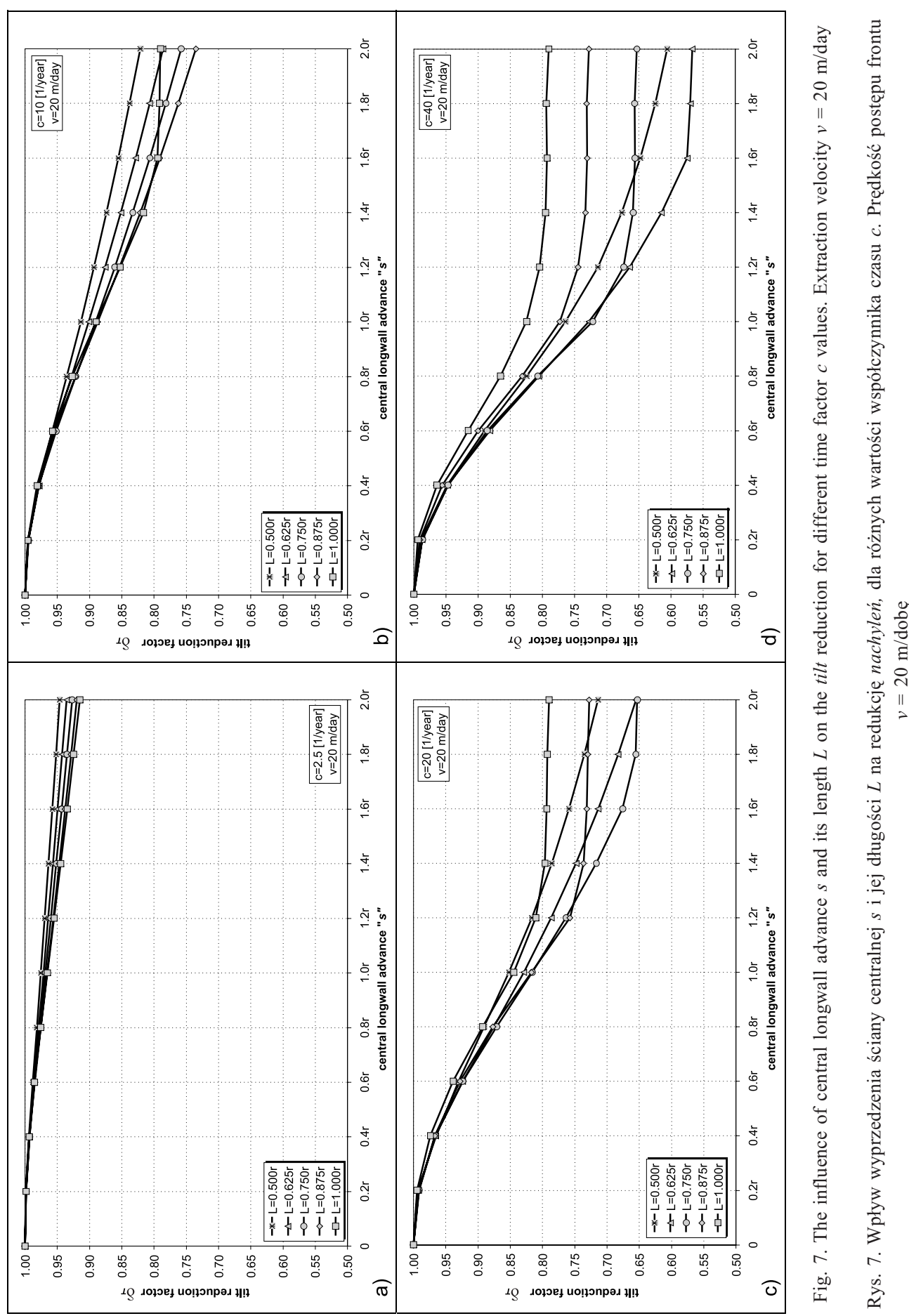




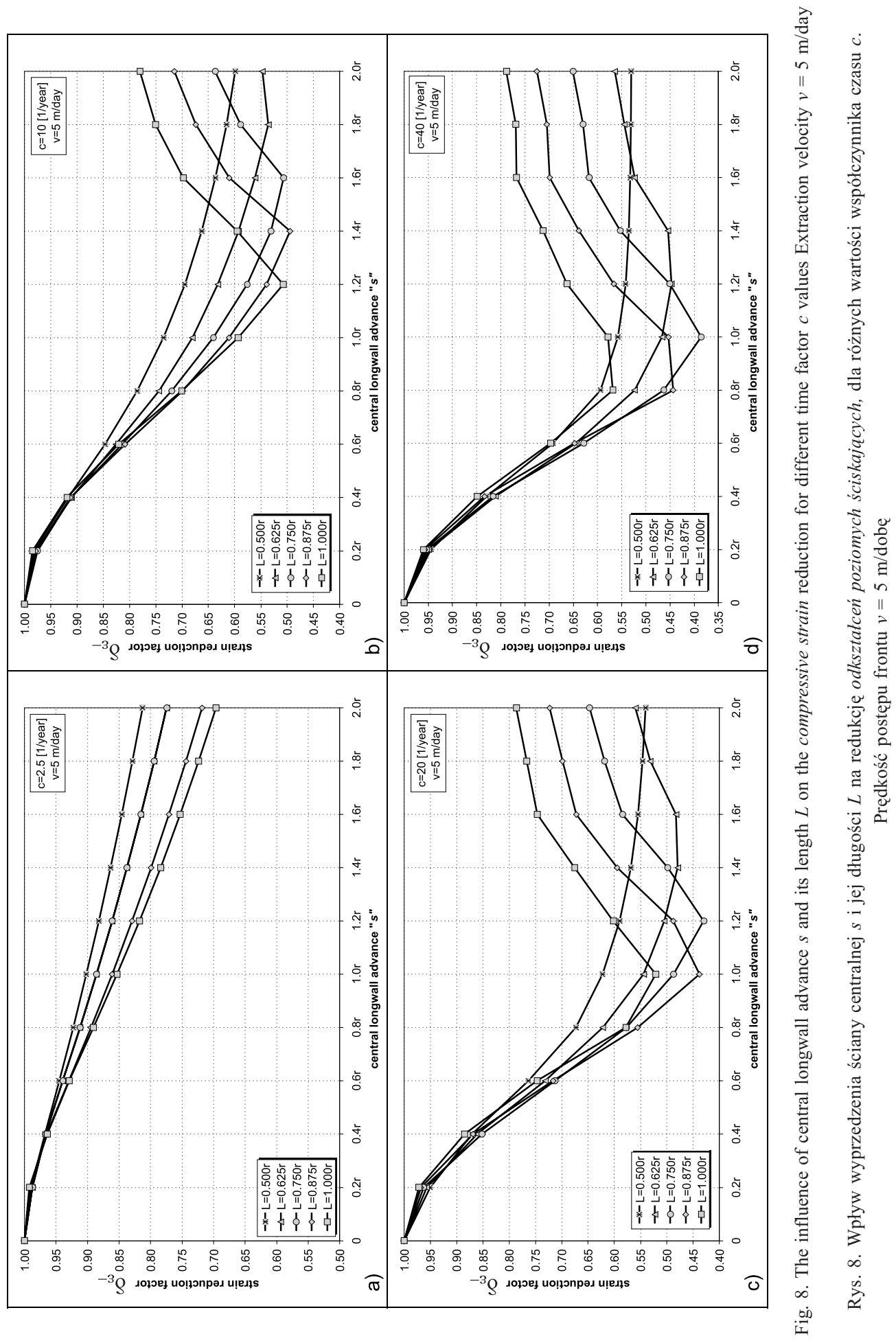




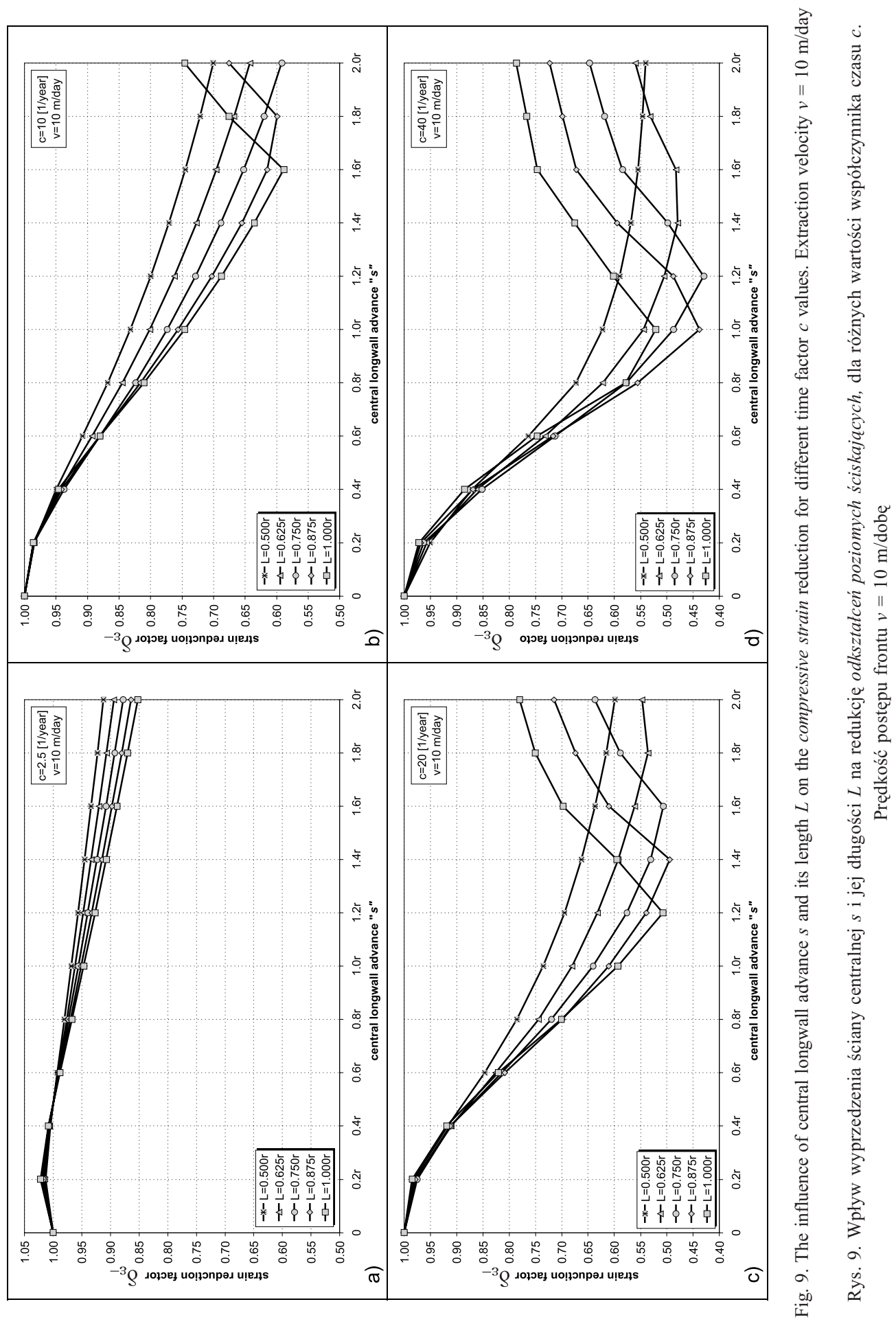




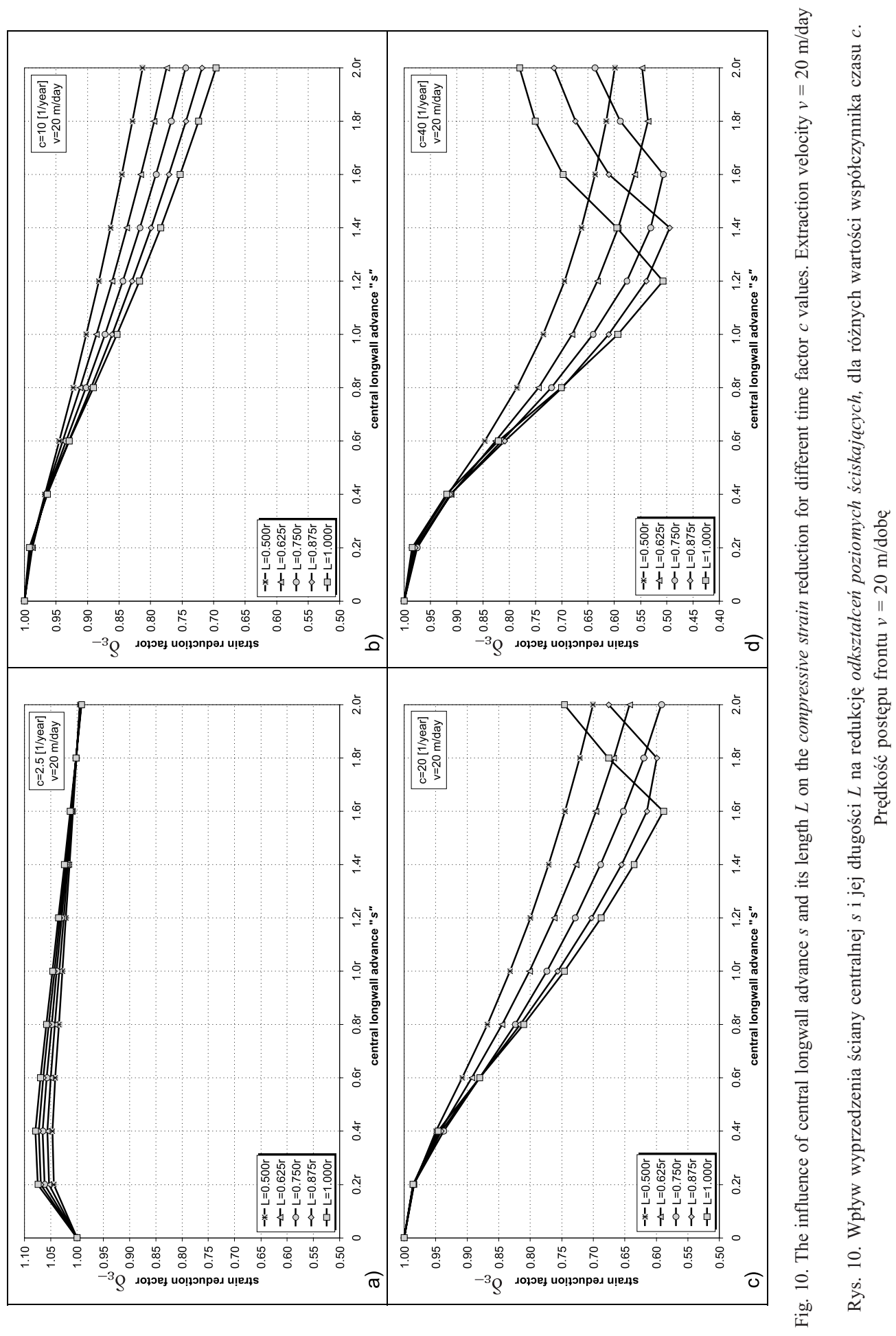




\section{Analysis of results}

Analyzing the drawings presented above, one can make the following conclusions and comments on the impact of various factors concerning the reduction of the tilt and horizontal strain, due to mining extraction carried out with the advancing longwall:

1. Regarding the impact of the central longwall advance $s$ on the reduction of the considered deformation indices in the range of active extraction edge influence:

- The optimum advance of the central longwall, taking into account tilt reduction, takes place at the $s$ value in the range of $1.4 r-1.6 r$. For horizontal tensile strain it is about $s=1.2 r-1.4 r$, and for horizontal compressive strain: $s=1.4 r-1.6 r$.

- In all analyzed cases, increasing the central longwall advance results in a greater reduction in tilt and horizontal tensile strain. In the range of greater time factor $c$ values (which characterizes weaker rock mass $-c \geq 10,1$ year) one can observe some limit value of $s$, above which there is no further reduction observed. It should also be noted that increasing the extraction velocity $v$ results in increasing this limit value of advance $s$ (e.g. Fig. 5d, 6d, 7d). The coefficient of tilt reduction $\delta_{T}$ for the extraction velocity $v=5 \mathrm{~m} /$ day can reach the amount of 0.53 in rock mass characterizing faster influences transition, up to 0.82 in another case - Fig. 5. In the case of front velocity $v=10 \mathrm{~m} /$ day, the above mentioned variability takes place in the range of $0.54-0.90$ (Fig. 6), and with $v=20 \mathrm{~m} /$ day reduced tilt values can reach the level of $0.57-0.95$ (Fig. 7). The values of tensile strain reduction coefficient $\delta_{\varepsilon}+$ for all considered extraction velocities can reach 0.46 for rock mass with faster influences transition ability, up to 0.80 otherwise.

- In the case of compressive strain, one can observe a different course of reduction depending on the central longwall advance $s$. Namely, from a certain value of $s$, there is a significant decrease, and then an increase in $\delta_{\varepsilon_{-}-}$; this does not, however, exceed the values for the linear shape of the extraction front. In addition, in this case there is also an increase in the limiting value along with increasing the extraction velocity (e.g. Fig. 8c, 9c, 10c). For a relatively low extraction velocity $(v<10 \mathrm{~m} /$ day) and rock mass with slow influences transition, one can observe the phenomenon in the shape of increasing of horizontal compressive strain, in the case of a central longwall advance $s$ not greater than $0.8 r$ (Fig. 9a, 10a).

2. Regarding the impact of the central longwall length $L$ on the reduction in the considered deformation indices in the range of active extraction edge influence:

- The length of the advancing central longwall has a different impact on the rate of deformation indices' reduction. Thus it is very difficult to clearly describe this relation for different mining-geological conditions. Analyzing the presented material, one may draw a very general conclusion that the length $L$ at the level of $0.625 r$ is a compromise value.

- In the case of tilt, for rock mass characterized by slow influences transition (Fig. 5a, $6 a, 7 a)$, the least evident reduction takes place for a central longwall length $L$ about 
$0.5 r$, and it is increasing together with growing values of $L$. Taking into account the rock mass properties, there is a reverse tendency visible - one can observe the best effect connected with tilt reduction at the $L$ values from the range $0.5 r-0.625 r$ (Fig. 5c, d; 6c, d; 7c, d).

- In the case of tensile strain, the most favourable is a central longwall length $L \approx 0.55 r$ with its increase, the reduction effect decreases.

- In the case of compressive strain, the situation is more ambiguous, although it is generally evident that greater reduction takes place with a central longwall of length $L>0.75 r$. On the other hand, an increase in its advance $s$ yields a considerable decrease in reduction effect in the case of a longer longwall (see Fig. 8c, d; 9c, d; $10 \mathrm{c}, \mathrm{d})$.

3. Regarding the impact of extraction velocity on the reduction in the considered deformation indices in the range of active extraction edge influence:

In the case of tilt and horizontal strain, the extraction velocity has a significant impact on the degree of reduction in these values. That fact is known from existing documentation (e.g. Kowalski 2007). However, considering this influence on the conditions of extraction with an advancing longwall, it is necessary to mention here three aspects of this issue:

- Firstly, the influence of face speed on the reduction in transient deformation values in relation to asymptotic - with great extraction velocity, a significant decrease in transient values is observed in the zone of active extraction edge influences. This effect has not been considered in this work due to its limited volume.

- Secondly, it is necessary to point out that as extraction speed increases, there is a decrease in the influence of the central longwall advance $s$, as well as its length $L$, on the deformation reduction. In light of the calculations performed for this paper, this effect applies to tilt and compressive strain (Fig. 5-10).

- Thirdly, one should keep in mind that apart from the "damping" effect of greater extraction velocity on the profile of the boundary zone of the subsidence trough, there is another very important factor which increases the hazard for building structures namely the rate of deformation increase over time. This factor has usually been considered as the most harmful to buildings and urban technical infrastructure. Thus, high-speed longwall progress is not recommended for extraction conducted in urban areas.

4. Regarding the impact of rock mass properties, it can generally be stated that the rock mass made up of strong rocks, where deformations are transferring relatively slowly from the roof of the extracted seam to the surface, results in a significant weakening of the central longwall dimensions' effect on the reduction in the considered deformation indices. 


\section{Concluding remarks}

This paper presents analysis of the impact of a special extraction system with an advancing longwall on the reduction in tilt and horizontal strain in the transient subsidence trough. This system can be used in cases of the planned extraction of protective pillars, especially pillars established for the protection of linear components of urban technical infrastructure.

Summing up the analyses presented in this paper, one can conclude that understanding the above listed issues concerning the impact of mining-geological conditions on the reduction in transient deformations in the vicinity of an active extraction edge formed by an advancing longwall can be helpful in designing such extraction under practical conditions. The graphs presented in Figures 5-10 can help in determining tilt and horizontal strain reduction for different mining conditions, especially related to the shape of the extraction front, without the need for any additional calculations. It is necessary to point out that the considerations presented were based on the results of computer simulations performed using a theoretical model, and they are presently difficult to verify in practice because of a lack of practical experience with such extractions.

The interactive model developed using Wolfram Mathematica allows analyses concerning the effects of natural and technical factors of underground mining's impact on the distribution of deformation on the surface for various cases of the extraction front layout.

It should also be noted that the practical application of extraction with advancing longwall will undoubtedly be difficult to implement under the present conditions in Polish coal mines, primarily due to unfavorable natural and technical factors. One should point out here the difficulties in operating three longwalls at the same time, due to existing natural hazards - mainly methane or rock bursts. These threats are unfortunately often encountered in Polish coal mines.

An extraction project of this kind is also challenging from an organizational point of view - a large concentration of production resulting in the concentration of the crew and equipment raises a number of logistical problems and safety issues.

However, taking into account that the Polish mining industry will be forced in the future to use these elements of a deposit covered by protective pillars, the results presented in this paper may help in such plans for underground extraction development.

\section{REFERENCES}

Chu d e k M. i in., 2004 - Ochrona środowiska w Górnośląskim i Donieckim Zagłębiu Węglowym. Wydawnictwo Pol. Śl., Gliwice.

Knothe S., 1953a - Równanie profilu ostatecznie wykształconej niecki osiadania. Archiwum Górnictwa i Hutnictwa, t. 1, z. 1. Kraków.

Kn othe S., 1953b - Wpływ czasu na kształtowanie się niecki osiadania. Archiwum Górnictwa i Hutnictwa, t. 1, z. 1, Kraków. 
K n o the S., 1984 - Prognozowanie wpływów eksploatacji górniczej. Wydawnictwo „Śląsk”. Katowice.

Kowalski A., 2007 - Nieustalone górnicze deformacje powierzchni w aspekcie dokładności prognoz. Wydawnictwo Głównego Instytutu Górnictwa. Katowice.

K rats ch H., 1983 - Mining subsidence engineering. Springer-Verlag.

Piwowarski W. i in. 1995 - Współczesne teorie ruchów górotworu i ich zastosowania. Wyd. AGH, Kraków.

S rok a A., 1999 - Dynamika eksploatacji górniczej z punktu widzenia szkód górniczych. Wyd. IGSMiE PAN, Kraków.

Strzałkowski P., 1998 - Model nieustalonych przemieszczeń pionowych górotworu w obszarze objętym oddziaływaniem eksploatacji górniczej. Zeszyty Naukowe Pol. Śl., s. Górnictwo, nr 237. Gliwice.

Ścigała R., 2008 - Komputerowe wspomaganie prognozowania deformacji górotworu i powierzchni wywołanych podziemną eksploatacją górniczą. Wydawnictwo Pol. Śl., Gliwice.

Wolfram Mathematica Documentation Center:

http://reference.wolfram.com/mathematica/guide/Mathematica.html

EKSPLOATACJA ZE ŚCIANĄ WYPRZEDZAJĄCĄ JAKO METODA OCHRONY OBIEKTÓW INFRASTRUKTURY TECHNICZNEJ I ELEMENT RACJONALNEJ GOSPODARKI ZLOŻEM

Słowa kluczowe

Wpływy podziemnej eksploatacji na powierzchnię, filary ochronne, minimalizacja wpływów

\section{Streszczenie}

Podziemna eksploatacja górnicza wywołuje wiele niekorzystnych zmian w środowisku naturalnym, a także może prowadzić do uszkodzeń obiektów budowlanych oraz infrastruktury technicznej. Aby chronić te obiekty, w pewnych sytuacjach wyznaczane są dla nich filary ochronne, w których - jak powszechnie wiadomo eksploatacja może być prowadzona tylko na specjalnych warunkach, zapewniających odpowiednią ochronę tych obiektów. Kopalnie z reguły rezygnują z eksploatacji filarów ochronnych, co powoduje określone straty złoża i zaburza racjonalne nim gospodarowanie.

Jedną z metod w zakresie profilaktyki górniczej dla obiektów powierzchniowych, która wydaje się być współcześnie możliwa do zastosowania, jest eksploatacja systemem ścianowym ze ścianą wyprzedzająca. Pozwala ona na ograniczenie deformacji dla tzw. obiektów liniowych, których typowymi przykładami są: szlaki kolejowe, szlaki drogowe, rurociagi.

Należy jednocześnie mieć na uwadze, że współcześnie praktyczne zastosowanie eksploatacji ze ściana wyprzedzającą niewątpliwie będzie trudne w realizacji, z uwagi na wiele niesprzyjających czynników naturalnych i technicznych. Należy tu przede wszystkim wskazać na trudności w prowadzeniu eksploatacji trzech ścian równocześnie z uwagi na zagrożenia naturalne, głównie metanowe oraz tąpaniami.

W artykule przedstawiono rozważania w zakresie wykorzystania tej metody eksploatacji do minimalizacji oddziaływania podziemnej eksploatacji górniczej na powierzchnię.

Dla celów analiz, przy wykorzystaniu systemu obliczeniowego Wolfram Mathematica, zbudowano model teoretyczny oparty na teorii W.Budryka-S.Knothego zarówno dla stanu asymptotycznego deformacji, jak i dla stanów nieustalonych. Dzięki możliwościom obliczeniowym programu Mathematica, możliwe było przeprowadzenie wielowariantowej analizy wpływu wyprzedzenia i długości ściany centralnej oraz prędkości postępu frontu na zmniejszenie nachyleń i odkształceń poziomych na powierzchni nad przedmiotową eksploatacją. Dodatkowo rozważania przeprowadzono dla różnych wartości współczynnika prędkości osiadania $c$, który w pewnym sensie charakteryzuje właściwości górotworu w zakresie prędkości przemieszczania się niecki obniżeniowej od stropu eksploatowanego pokładu do powierzchni.

Przedstawione w artykule wyniki mogą być pomocne przy doborze odpowiednich parametrów ściany wyprzedzającej, w przypadku projektowania takiej eksploatacji w filarach ochronnych obiektów liniowych. 
A MINING EXTRACTION SYSTEM WITH ADVANCING LONGWALL AS A METHOD OF PROTECTING TECHNICAL OBJECTS AND AN ELEMENT OF RATIONAL DEPOSIT MANAGEMENT

$$
\text { Key words }
$$

Underground mining influences, protective pillars, minimization of mining influences

\section{Abstract}

Underground mining leads to many adverse changes in the natural environment and also affects building structures and elements of urban technical infrastructure. Protective pillars are usually designed to protect these objects. As is well known, extraction within these pillars may only be conducted taking special actions to insure proper protection of existing infrastructure against mining damages. Mines usually refrain from the extraction of protective pillars, which results in the specific loss of reserves and interferes with the rational management of a deposit.

At present, longwall extraction using the so-called "advancing longwall" appears to be one of few feasible methods. This method can be used for the protection of linear objects like railways, motorways, pipelines, etc.

This paper presents considerations concerning the use of an extraction system with an advancing longwall for terrain deformation minimization. For these purposes, a theoretical model was designed using the Wolfram Mathematica 9 calculation system. The W. Budryk-S. Knothe theory was employed to build the model for asymptotic and transient state of deformation. The solution contains a full space-time model, enabled for analyses of front shapes, its dimensions and the extraction velocity's influence on tilt and horizontal strain values along the longitudinal axis of a linear object of technical infrastructure located at the surface. The rock mass properties were considered too, using selected values of time factor $\mathrm{c}$ which can be viewed as a parameter describing the rate of subsidence trough transition from the extracted seam toward the surface.

The results presented in this paper may be helpful in designing the proper parameters of a central longwall when planning the extraction of protective pillars. 